\title{
ANALISIS KEGAGALAN PRODUK CACAT DENGAN KOMBINASI SIKLUS PLAN- DO-CHECK-ACTION (PDCA) DAN METODE FAILURE MODE AND EFFECT ANAL YSIS (FMEA)
}

\author{
Rini Alfatiyah \\ Prodi Teknik Industri Fakultas Teknik Universitas Pamulang, Tangerang Selatan Banten 15417, Indonesia, \\ dosen00347@unpam.ac.id
}

\begin{abstract}
ABSTRAK
PT. KMK Global Sports 2 adalah produsen sepatu Converse. PT. KMK Global Sports 2 memproduksi lebih dari satu juta sepatu per tahun, dalam produksi produk yang baik dan cacat, yang disebabkan oleh produk yang rusak yang disebabkan oleh berbagai faktor seperti kesalahan manusia, bahan baku, kesalahan mesin dan lain-lain. Untuk mengatasinya, penulis menerapkan Plan-Do-Check-Action (PDCA), metode PT, mode kegagalan dan analisis kinerja (FMEA). KMK Global Sports 2. Setelah menerapkan dua metode yang diperoleh, bahan di bawah rasio cacat rata-rata turun $0,87 \%$ dari nilai cacat rata-rata sebelumnya pada tahun 2017 sebesar 1,48\%, dan setelah peningkatan persentase cacat rata-rata selama delapan bulan ke depan adalah $0,61 \%$
\end{abstract}

.Kata Kunci: Produk Cacat, Hot Press, Siklus PDCA, Metode FMEA

\section{PENDAHAHULUAN}

Persaingan ekonomi global adalah sesuatu yang akan dihadapi oleh setiap perusahaan di dunia. Berdasarkan latar belakang di atas, maka perumusan masalah dalam penelitian ini adalah sebagai berikut:

1. Faktor apa saja yang menyebabkan produk cacat outsole pada proses hot press di PT. KMK Global Sports 2?

2. Bagaimana mengaplikasikan Siklus PlanDo-Check-Action (PDCA) dan Metode Failure Mode And Effect Analysis (FMEA) PT. KMK Global Sports 2?

Adapun tujuan yang ingin dicapai dalam penelitian ini adalah:

1. Untuk mengetahui faktor apa saja yang menyebabkan produk cacat outsole pada proses hot press di PT. KMK Global Sports 2.

2. Untuk mengaplikasikan Siklus Plan-DoCheck-Action (PDCA) dan Metode Failure Mode And Effect Analysis (FMEA) PT. KMK Global Sports 2.

\section{DASAR TEORI}

\section{A.Faktor-faktor Yang Mempengaruhi Kualitas}

Kualitas produk secara langsung dipengaruhi oleh 9 bidang dasar atau 9M. Pada masa sekarang ini industri disetiap bidang bergantung pada sejumlah besar kondisi yang membebani produksi melalui suatu cara yang tidak pernah dialami dalam periode sebelumnya. Fandy Tjiptono \& Anastasia Diana (2000) sebagai berikut:

1. Market (Pasar)

2. Money (Uang)

3. Management (Manajemen)

4. Man (Manusia)

5. Motivation (Motivasi)

6. Material (Bahan)

7. Machine and Mecanization (Mesin dan Mekanisme)

8. Modern Information Metode (Metode Informasi Modern)

9. Mounting Product Requirment (Persyaratan Proses Produksi)

\section{B.Produk Cacat}

Tingkat keparahan adalah peringkat yang menunjukkan keseriusan efek dari mode 
kegagalan desain potensial. Tingkat keparahan selalu berlaku untuk efek mode kegagalan. Bahkan, ada korelasi langsung antara efek dan tingkat keparahan. Misalnya, jika efeknya kritis, tingkat keparahannya tinggi. Sebaliknya, jika efeknya mengganggu, tingkat keparahannya sangat rendah. Tingkat keparahan ditinjau dari perspektif sistem, desain itu sendiri, sistem lain, produk, pelanggan, dan / atau peraturan pemerintah. Untuk tujuan evaluasi penilaian yang mencerminkan masalah organisasi sehubungan dengan pelanggan dan / atau peraturan. Dalam desain FMEA peringkat keparahan harus didasarkan pada efek terburuk dari mode kegagalan. Ketika selesai, peringkat mode kegagalan berdasarkan tingkat keparahan efeknya. Potensi Penyebab Kegagalan (16). Penyebab mode kegagalan desain adalah kekurangan desain yang menghasilkan mode kegagalan. Harus ditekankan berulang kali bahwa ketika seseorang berfokus pada penyebab, ia harus melihat pada akar permasalahan, bukan gejala kegagalan.

Untuk melakukan pekerjaan dengan baik yang berpotensi menyebabkan penyebab kegagalan identifikasi, seseorang harus memahami sistem dan desain, dan menanyakan pertanyaan yang sesuai. Spesifisitas sangat penting. Semakin banyak memperbesar pada penyebab root, semakin baik memahami kegagalan.

\section{C.Jenis-jenis Produk Cacat}

Menurut Mursyidi (2008: 115) "Produk rusak merupakan produk gagal secara teknis atau secara ekonomis tidak dapat diperbaiki menjadi produk yang sesuai dengan standar mutu yang ditetapkan. Berbeda dengan sisa bahan, produk rusak sudah menelan semua unsur biaya produksi (bahan, tenaga kerja, dan biaya overhead pabrik)".Produk cacat yang terjadi dapat bersifat normal dan dapat pula bersifat abnormal.

\section{D.Faktor-faktor Penyebab Produk Cacat}

Sumber penyebab masalah kualitas yang ditemukan berdasarkan prinsip $7 \mathrm{M}$, yaitu: (Gasperz, 2005: 241-243)

1. Manpower (tenaga kerja).

2. Machine (mesin).

3. Methods (metode kerja).

4. Materials (bahan baku dan bahan penolong).

5. Media. Motivation (motivasi).

6. Money (keuangan).

\section{E.Kerugian-kerugian Yang Ditimbulkan Ketika Terjadi Produk Cacat}

Banyak sekali kerugian-kerugian yang timbul ketika terjadi produk cacat pada saat produksi baik itu kerugian fisik maupaun kerugian nonfisik antara lain:

1. Pemborosan bahan baku dan bahan penolong.

2. Pemborosan energy yang terpakai pada saat proses produksi.

3. Tenaga yang telah dikeluarkan untuk kegiatan produksi.

4. Waktu yang terbuang sia-sia.

5. Proses transportasi selama proses produksi.

6. Biaya, baik itu biaya operasional maupun biaya non operasional.

7. Pemikiran yang telah dicurahkan selama proses produksi.

8. Tempat dan fasilitas yang telah dipakai saat produksi.

\section{F.Tahapan proses FMEA}

1. proses FMEA adalah analisis / metode disiplin untuk mengidentifikasi mode kegagalan potensial atau yang diketahui dan memberikan tindak lanjut dan tindakan korektif sebelum proses produksi pertama terjadi. Sebuah pro-

2. duction run dipandang sebagai proses yang menghasilkan produk atau layanan untuk pelanggan tertentu dengan tujuan mendapatkan bayaran. Definisi run pertama ini sangat penting karena tidak termasuk run sampel awal (ISR), uji 
coba berjalan, run prototipe sesekali (s), dan sebagainya. Ambang batas dari proses produksi pertama adalah penting karena sampai saat itu memodifikasi dan / atau mengubah desain biasanya bukan peristiwa besar. Pada titik validasi pertama, produksi, proses, produk, dan prosedur didefinisikan. Pelanggan memiliki peran penting dalam mendefinisikan proses, produk, prosedur, dan sebagainya. Namun, setelah titik itu, pelanggan menjadi terlibat melalui surat penyimpangan, pengabaian perubahan, atau pemberitahuan formal lainnya.

3. Proses FMEA biasanya dilakukan melalui serangkaian langkah untuk memasukkan tenaga kerja, mesin, metode, bahan, pengukuran, dan pertimbangan lingkungan. Tentu saja, masing-masing komponen ini memiliki komponennya sendiri, yang dapat bereaksi secara individu, bersama-sama, atau sebagai interaksi untuk menciptakan kegagalan. Karena konvolusi ini, menyelesaikan proses FMEA lebih kompleks dan memakan waktu daripada sistem dan / atau desain FMEA.

4. Proses FMEA adalah proses evolusi (dinamis sebagai lawan statis). Ini melibatkan penerapan berbagai teknologi dan metode untuk menghasilkan output proses yang efektif. Hasilnya adalah produk bebas cacat; atau informasi yang dapat digunakan sebagai input untuk produk, perakitan, dan / atau layanan FMEA.

5. Pemilihan teknologi yang tepat dapat mencakup permintaan pelanggan, pemanfaatan sistem yang ada, pendekatan standar dan / atau.

\section{G.Pengertian dan Siklus PDCA}

PDCA adalah singkatan dari Plan, Do, Check dan Action yaitu siklus peningkatan proses (Process Improvement) yang berkesinambungan atau secara terus menerus seperti lingkaran yang tidak ada akhirnya. Konsep siklus PDCA (Plan, Do, Check dan Action) ini pertama kali diperkenalkan oleh seorang ahli manajemen kualitas dari Amerika Serikat yang bernama Dr. William Edwards Deming. Berikut ini adalah siklus PDCA (PDCA Cycle):

1. Plan (Merencanakan)

2. Do (Melaksanakan)

3. Check (Memeriksa)

4. Action (Menindak)

\section{H.Diagram Kontrol Proporsi (p)}

Untuk produk yang dinyatakan dalam data atribut dengan penggolongan dilakukan atas dua kategori atau mungkin lebih, diperlukan diagram kontrol tersendiri jika ingin melakukan pengontrolan kualitas atas produk tersebut. Dalam hal ini disini hanya akan diuraikan bagaimana diagram kontrol dibuat untuk produk yang digolongkan kedalam satu dari dua kategori ialah rusak atau baik.

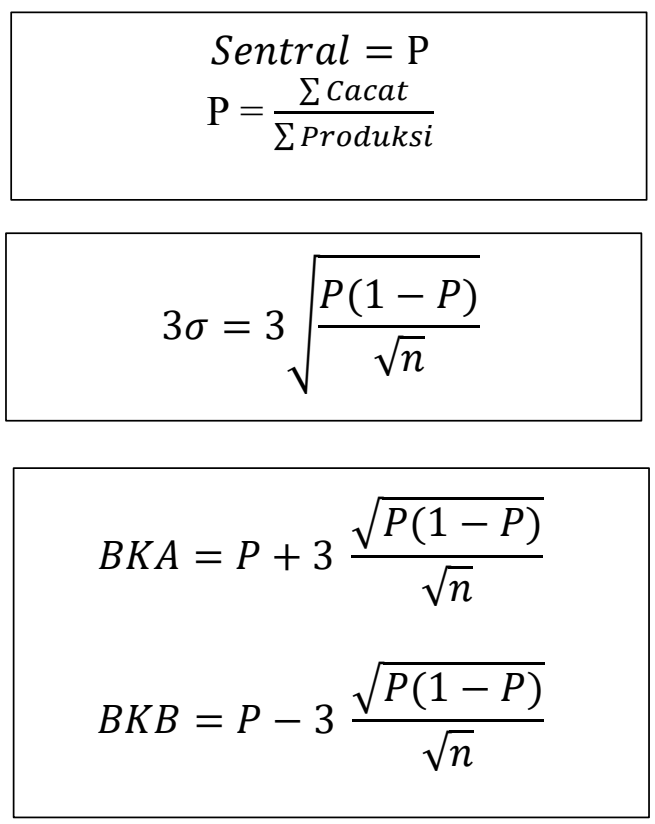

Untuk $\mathrm{P}=$ rata-rata untuk proporsi barang yang rusak. Sedangkan,

Untuk $\mathrm{n}=$ ukuran tiap sampel yang telah diambil.

Perbandingan antara banyaknya cacat 
dengan semua pengamatan, yaitu setiap produk yang diklasifikasikan sebagai "diterima" atau "ditolak" (yang di perhatikan banyaknya produk cacat). Langkah-langkah pembuatan peta kendali - p sebagai berikut:

1. Tentukan ukuran contoh/subgrup yang cukup besar $(\mathrm{n} \geq 30)$.

2. Kumpulkan banyaknya subgrup sedikitnya 20-25 sub-grup.

3. Hitung untuk setiap subgrup nilai proporsi unit yang cacat yaitu: $\mathrm{P}=$ jumlah unit cacat/ukuran subgrup.

4. Hitung nilai rata-rata dari $p$, yaitu $p$ dapat dihitung dengan berikut:

$$
\bar{P}=\frac{\sum \text { Cacat }}{\sum \text { Pengamatan }}
$$

5. Hitung batas kendali dari peta kendali $\mathrm{p}$ dengan rumus sebagai berikut:

$$
B K A=\frac{\sum B K A}{n}
$$

$$
B K A=\frac{\sum B K B}{n}
$$

6. Plot data proporsi (presentase) unit cacat serta amati apakah data tersebut berada didalam batas kendali atau diluar batas kendali.

\section{I.Diagram Sebab Akibat}

Faktor-faktor penyebab terletak pada bagian kiri, sedangkan akibat yang ditimbulkan merupakan karakteristik mutu atau kualitas yang merupakan tujuan dari sistem pada bagian kanan bagan. Diagram sebab akibat seperti Gambar 1.

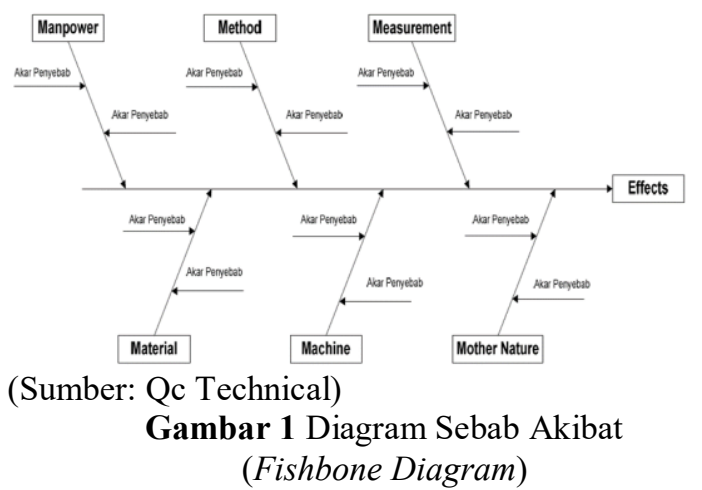

\section{J.Failure Mode and Effect Analysis (FMEA)}

desain FMEA adalah analisis / metode disiplin untuk mengidentifikasi mode kegagalan potensial atau yang diketahui dan memberikan tindak lanjut dan tindakan korektif sebelum proses produksi pertama terjadi. Jalankan produksi pertama

dipandang sebagai proses yang menghasilkan produk atau layanan untuk pelanggan tertentu dengan tujuan mendapatkan bayaran. Definisi run pertama ini sangat penting karena tidak termasuk run sampel awal (ISR), uji coba berjalan, uji coba prototipe oklusif, dan sebagainya. Ambang batas dari menjalankan produksi pertama adalah penting, karena sampai saat itu memodifikasi dan / atau mengubah desain bukanlah masalah utama. Namun, setelah titik itu, pelanggan terlibat melalui surat penyimpangan, pengabaian perubahan, atau semacam pemberitahuan formal lainnya.

Dalam hal ini Metode Failure Mode and Effect Analysis (FMEA) sebagai metode analisa dengan menggunakan rangkaian penilai kesetiap sub-sub yang berpotensi untuk menyebabkan masalah.

$$
\mathrm{RPN}=\mathrm{S} \times \mathrm{O} \times \mathrm{D}
$$




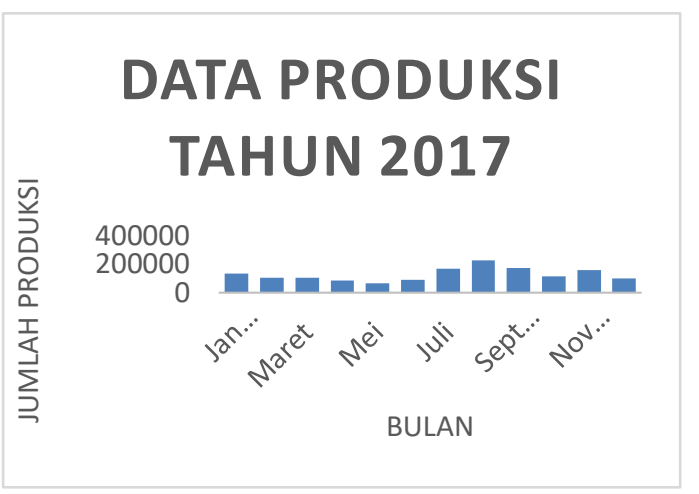

Dimana.

RPN : Risk Priority Number/ nilai prioritas masalah.

$\mathrm{S}$ : Severity/ nilai potensial kegagalan yang akan terjadi.

$\mathrm{O}$ : Occurance/ nilai peluang yang akan menyebabkan kegagalan.

D : Detection/ nilai deteksi yang menyebabkan kegagalan.

\section{HASIL DAN PEMBAHASAN}

Tabel 1 Data Produksi Outsole AS Brown 475

\begin{tabular}{|c|l|c|c|c|}
\hline No & Bulan & Produksi & Cacat & $\mathbf{\%}$ \\
\hline 1 & Januari & 131210 & 1325 & $1,01 \%$ \\
\hline 2 & Februari & 104654 & 1421 & $1,36 \%$ \\
\hline 3 & Maret & 102476 & 1559 & $1,52 \%$ \\
\hline 4 & April & 87407 & 945 & $1,08 \%$ \\
\hline 5 & Mei & 67453 & 983 & $1,46 \%$ \\
\hline 6 & Juni & 87923 & 1113 & $1,27 \%$ \\
\hline 7 & Juli & 165.780 & 2.453 & $1,28 \%$ \\
\hline 8 & Agustus & 226.987 & 3.528 & $1,55 \%$ \\
\hline 9 & September & 174.327 & 3.350 & $1,92 \%$ \\
\hline 10 & Oktober & 115.389 & 2.065 & $1,79 \%$ \\
\hline 11 & November & 155.688 & 2.365 & $1,52 \%$ \\
\hline 12 & Desember & 99.576 & 1.390 & $1,40 \%$ \\
\hline & Total & $\mathbf{1 . 5 1 8 . 8 7 0}$ & $\mathbf{2 2 . 4 9 7}$ & $\mathbf{1 , 4 8 \%}$ \\
\hline
\end{tabular}

(Sumber: PT. KMK Global Sports 2)

Berdasarkan Tabel 1 menunjukkan jumlah persentase produk cacat yang terjadi tahun 2017 sebanyak 1,48\%, sehingga total produk cacat yang terjadi pada tahun 2017 sebanyak 22497 Pcs. Adapun gambaran dari data produksi outsole AS Brown 475 pada tahun 2017 dapat dilihat dengan menggunakan diagram seperti pada Gambar 2.

(Sumber: PT KMK Global Sports 2)

Gambar 2 Diagram Data Produksi Tahun 2017

Dan berdasarkan dari data hasil produksi dan hasil cacat pada tahun 2017 terjadi pada bulan Agustus dengan hasil produksi yang tinggi dan hasil cacat juga tinggi. Adapun gambaran hasil cacat dapat dilihat pada Gambar 3.

\section{Data Produk Cacat Tahun} 2017

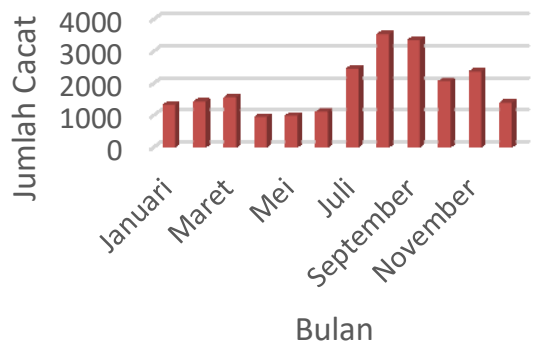

(Sumber: PT KMK Global Sports 2)

Gambar 3 Diagram Data Cacat Tahun 2017

\section{Jenis-jenis Produk Cacat Outsole}

Terdapat beberapa jenis produk cacat yang terjadi di department technical PT. KMK Global Sports 2 selama proses produksi sedang berjalan antara lain:

1. Kurang Bahan

2. Logo Berbayang

3. Kotor Bahan

4. Kurang Angin

5. Pecah-pecah

6. Gosong

Berdasarkan ke enam jenis cacat outsole AS Brown 475 telah di ketahui masing-masing jumlah cacat menurut jenisnya. Adapun jenis dan jumlah cacat dapat di lihat pada Tabel 2.

Tabel 2 Jenis Cacat dan Jumlah Cacat Tahun 2017

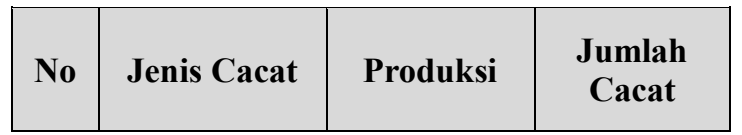




\begin{tabular}{|c|l|c|c|}
\hline 1 & $\begin{array}{l}\text { Kurang } \\
\text { Bahan }\end{array}$ & 1.518 .870 & 19.048 \\
\hline 2 & $\begin{array}{l}\text { Logo } \\
\text { Berbayang }\end{array}$ & 1.518 .870 & 1.392 \\
\hline 3 & Kotor Bahan & 1.518 .870 & 1.370 \\
\hline 4 & $\begin{array}{l}\text { Kurang } \\
\text { Angin }\end{array}$ & 1.518 .870 & 1.340 \\
\hline 5 & Pecah-pecah & 1.518 .870 & 1.143 \\
\hline 6 & Gosong & 1518870 & 754 \\
\hline
\end{tabular}

(Sumber: PT KMK Global Sports 2)

\section{Prioritas Cacat Dengan Diagram Pareto}

Tabel 3 Data Produk Cacat Tahun 2017

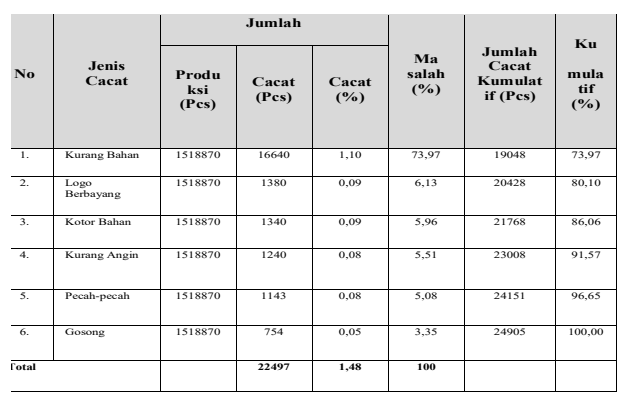

(Sumber: Diolah Sendiri Tahun 2018)

\section{Failure Mode and Effect Analysis (FMEA)}

Secara umum, ada dua tipe dasar teknik evaluasi proses yang digunakan pada tahap awal:

1. Mempelajari studi kemampuan. Studi semacam itu digunakan untuk menentukan kemampuan inheren elemenelemen spesifik dari proses produksi. Contohnya termasuk kemampuan penerimaan alat berat, studi potensi proses (kemampuan jangka pendek), dan kemampuan jangka panjang.

2. Evaluasi proses wajib. Seperti disebutkan, sulit untuk mengevaluasi semua parameter proses. Dengan demikian, setiap perusahaan menetapkan poin evaluasi wajib untuk variabel spesifik yang sangat penting untuk operasi dan / atau pelanggan. Mereka dapat dibantu dalam identifikasi ini dengan:

1. Kebutuhan pelanggan

2. Regulasi pemerintah:

3. Pedoman teknik internal
4. Desain FMEA

5. Standar/pedoman industri

6. Praktek yang diterima secara umum

7. Pengadilan melalui kewajiban produk

Beberapa poin evaluasi mungkin:

Sertifikasi operator. Sertifikasi mungkin diperlukan untuk keterampilan kritis (dengan kata lain, operator boiler, tukang las).

Pemeriksaan alat. Alat, jig, dan perlengkapan mungkin diperlukan untuk divalidasi.Proses kritis. Sebagian besar proses kritis sebagaimana didefinisikan oleh keselamatan, pelanggan, atau peraturan pemerintah memerlukan evaluasi dan persetujuan sebelumnya (dengan kata lain, praktis semua proses obat-obatan dan peralatan medis, perawatan panas).

Uji operasi. Sebagian besar operasi pengujian yang kompleks memerlukan peninjauan dan persetujuan untuk memastikan keakuratan.

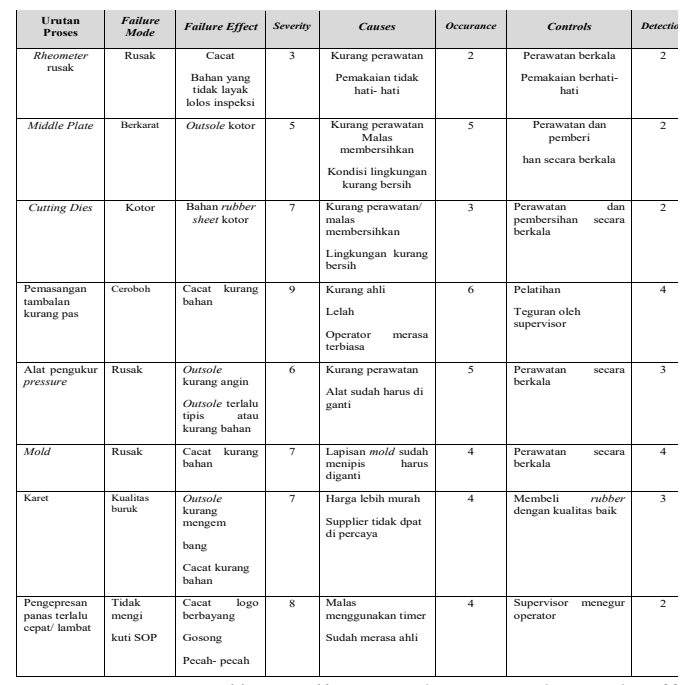

Tabel 4 Hasil Analisa Failure Mode and Effect Analysis

(Sumber: Diolah Sendiri Tahun 2018)

Mencari Faktor Penyebab Masalah Dengan Diagram Fishbone 


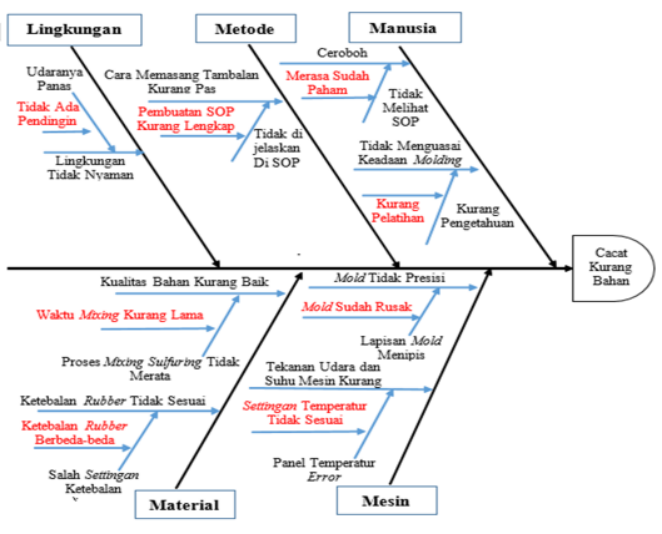

(Sumber: Diolah Sendiri Tahun 2018)

Gambar 4. Diagram Sebab-Akibat

\section{Mencari Faktor Penyebab Dominan Dengan Nominal Group Technique (NGT).}

Rekapitulasi NGT (Nominal Group Technique)

\begin{tabular}{|c|l|c|c|c|c}
\hline \multirow{2}{*}{ NO } & \multicolumn{1}{|c|}{ Faktor Penyebab } & \multicolumn{3}{|c|}{ Tim Penilai } & \multirow{2}{*}{ Score } \\
\cline { 3 - 5 } & & Operator & Leader & Supervisor & \\
\hline \hline 1 & Operator merasa sudah paham & 1 & 2 & 2 & 5 \\
\hline 2 & Operator kurang pelatihan & 2 & 1 & 3 & 6 \\
\hline 3 & Pembuatan SOP kurang lengkap & 3 & 4 & 1 & 8 \\
\hline 4 & Tidak ada pendingin ruangan & 5 & 6 & 5 & 16 \\
\hline 5 & Mold sudah rusak & 8 & 7 & 7 & 22 \\
\hline 6 & Settingan temperatur tidak sesuai & 6 & 5 & 6 & 17 \\
\hline 7 & Waktu mixing kurang lama & 7 & 8 & 8 & 23 \\
\hline 8 & Ketebalan rubber berbeda-beda & 4 & 3 & 4 & 11 \\
\hline
\end{tabular}

(Sumber: Diolah Sendiri Tahun 2018)

Tahapan Do Merancanakan Perbaikan Dengan 5W-1H

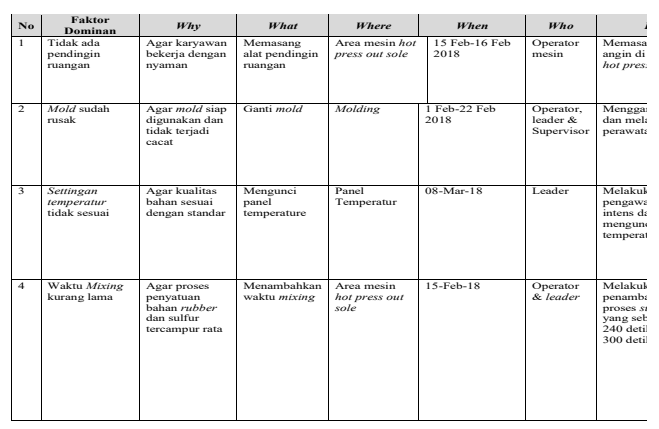

Tabel 5 Rencana Perbaikan dengan Prinsip 5W+1H (Sumber: Diolah Sendiri Tahun 2018)

Melakukan Perbaikan
Tabel 5 Melakukan Perbaikan

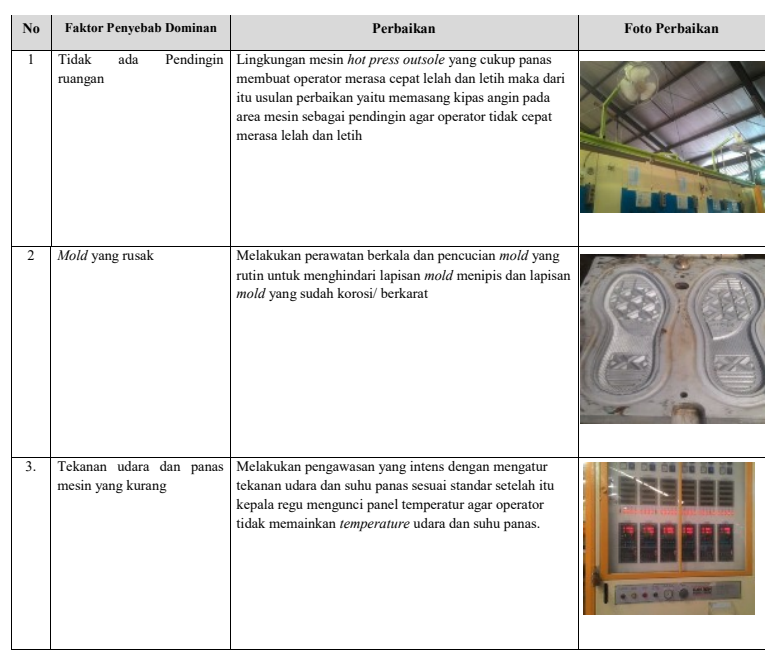

(Sumber: Hasil Pengolahan Sendiri )

Tahapan Check (Hasil Perbandingan Sebelum dan Sesudah Perbaikan)

Tabel 6 Hasil Perbandingan Sebelum Perbaikan

\begin{tabular}{|c|l|c|c|}
\hline No & \multicolumn{1}{|c|}{$\begin{array}{c}\text { Bulan } \\
(\mathbf{2 0 1 7})\end{array}$} & Produksi & Cacat \\
\hline 1 & Januari & 131.210 & 1.325 \\
\hline 2 & Februari & 104.654 & 1.421 \\
\hline 3 & Maret & 102.476 & 1.559 \\
\hline 4 & April & 87.407 & 945 \\
\hline 5 & Mei & 67.453 & 983 \\
\hline 6 & Juni & 87.923 & 1.113 \\
\hline 7 & Juli & 165.780 & 2.453 \\
\hline 8 & Agustus & 226.987 & 3.528 \\
\hline 9 & September & 174.327 & 3.350 \\
\hline 10 & Oktober & 115.389 & 2.065 \\
\hline 11 & November & 155.688 & 2.365 \\
\hline 12 & Desember & 99.576 & 1.390 \\
\hline & Total & $\mathbf{1 . 5 1 8 . 8 7 0}$ & $\mathbf{2 2 . 4 9 7}$ \\
\hline
\end{tabular}

Tabel 6 Hasil Perbandingan Sesudah Perbaika 


\begin{tabular}{|c|c|c|c|}
\hline No & Bulan (2018) & Produksi & Cacat \\
\hline $\mathbf{1}$ & Januari & 135.400 & 986 \\
\hline $\mathbf{2}$ & Februri & 125.600 & 1.002 \\
\hline $\mathbf{3}$ & Maret & 245.600 & 1.100 \\
\hline $\mathbf{4}$ & April & 145.000 & 867 \\
\hline & Total & $\mathbf{6 5 1 . 6 0 0}$ & $\mathbf{3 . 9 5 5}$ \\
\hline
\end{tabular}

(Sumber: PT. KMK Global Sports 2)

\section{PERBANDINGAN CACAT 2017 DAN 2018}

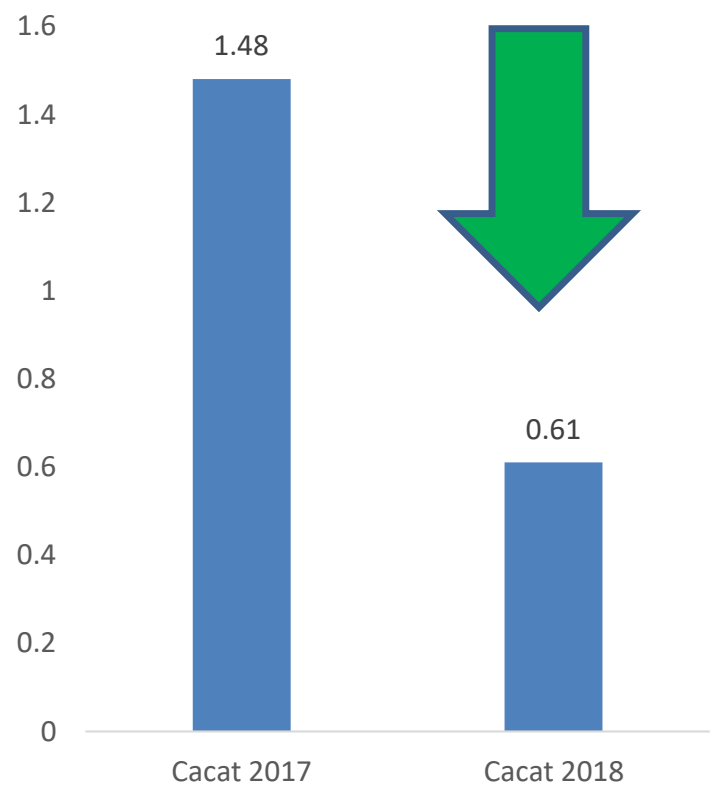

(Sumber: Pengolahan Sendiri Tahun 2018)

Gambar 5 Diagram Hasil Perbandingan

Tahapan Action (Membuat Standarisasi)

Tabel 7 Standarisasi Perbaikan

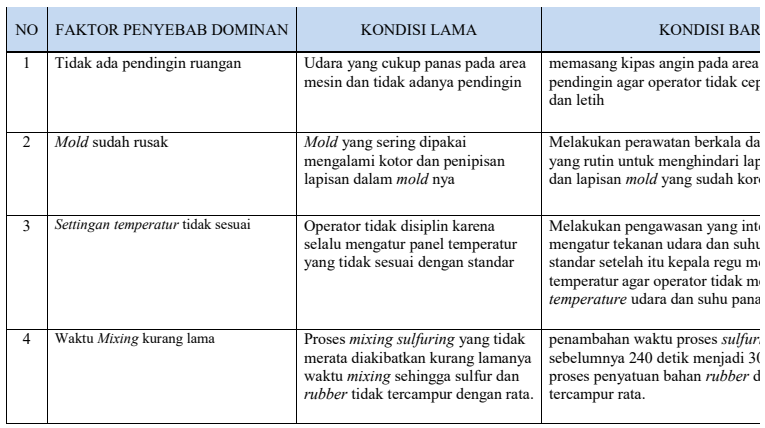

\section{KESIMPULAN}

1. Faktor yang menyebabkan produk cacat outsole pada proses hot press di PT. KMK Global Sports 2 adalah sebagai berikut:

a. Tidak ada pendingin ruangan.

b. Mold sudah rusak.

c. Settingan temperatur tidak sesuai.

d. Waktu mixing kurang lama.

2. Setelah mengaplikasikan Siklus PlanDo-Check-Action (PDCA) dan Metode Failure Mode And Effect Analysis (FMEA) PT. KMK Global Sports 2 didapat cacat kurang bahan mengalami penurunan rata-rata persentase cacat sebesar $0,87 \%$ dari sebelumnya nilai rata-rata persentase cacat pada tahun 2017 sebesar $1,48 \%$ dan setelah perbaikan dengan nilai rata-rata persentase cacat delapan bulan berikutnya sebesar $0,61 \%$.

\section{DAFTAR PUSTAKA}

Basjir, M., Supriyanto, H., \& Suef, M. (2014). Pengembangan Model Penentuan Prioritas Perbaikan Terhadap Mode Kegagalan Komponen Dengan Metodologi FMEA, Fuzzy Dan Topsis Yang Terintegrasi.

Bastuti, Sofian. (2016). Analisis Pengendalian Kualitas untuk Menurunkan Klaim Internal dengan Mengaplikasikan Metode PDCA pada 
Seksi Marking di PT. Surya Toto Indonesia, Tbk.

Benneyan, J. C., \& Chute, A. D. (1993). SPC, Process Improvement, and The Deming PDCA Circle in Freight Administration. Production and Inventory Management Journal, 34(1), 35.

Nanda, L., Hartanti, L. P., \& Runtuk, J. K. (2014). Analisis Risiko Kualitas Produk dalam Proses Produksi Miniatur Bis dengan Metode Failure Mode and Effect Analysis pada Usaha Kecil Menengah Niki Kayoe.

Nur Nasution, M.Sc.,APU. 2015. Manajemen Mutu Terpadu, edisi ketiga. PT Ghalia Indonesia, Bogor.

Pires, d. S., Hékis, H. R., Lucas Ambrósio, B. O., Jamerson, V. Q., Fernanda Cristina Barbosa, P. Q., \& Ricardo Alexsandro de, M. V. (2013). Implementation of A Six Sigma Project in a 3M Division of Brazil. The International Journal of Quality \& Reliability Management, 30(2), 129141.

Soliman, M. H. A. (2015). A New Routine for Culture Change. Industrial Management, 57(3), 25-30,5.

Sugiyono. 2015. Statistika Untuk

Penelitian. PT. Alfabeta, Bandung. 